\title{
SECRETIN: SPECIFIC BINDING TO RAT BRAIN MEMBRANES
}

\author{
ROBERT T. FREMEAU, JR., ${ }^{*}$ ROBERT T. JENSEN, $\ddagger$ CLIVEL G. CHARLTON,§ \\ RUSSELL L. MILLER, $\S$ THOMAS L. O'DONOHUE, \| AND TERRY W. MOODY ${ }^{*, 1}$
}

* Department of Biochemistry, The George Washington University School of Medicine and Health Sciences, Washington, D.C. 20037, $¥$ Section on Gastroenterology, Digestive Disease Branch, National Institute of Arthritis, Metabolism and Digestive Diseases, Bethesda, Maryland 20205, \$ Department of Pharmacology and Medicine, Division of Clinical Pharmacology, College of Medicine, Howard University, Washington, D.C. 20059, and \| Experimental Therapeutics Branch, National Institute of Neurological and Communicative Disorders and Stroke, Bethesda, Maryland 20205

Received November 18, 1982; Revised March 7, 1983; Accepted March 7, 1983

\begin{abstract}
The binding of $\left.{ }^{[25} \mathrm{I}\right]$ secretin to rat brain membranes was investigated. Radiolabeled secretin bound with high affinity $\left(K_{D}=0.2 \mathrm{nM}\right)$ to a single class of noninteracting sites. Binding was specific, saturable, and reversible. Regional distribution studies indicated that the specific binding was greatest in the cerebellum, intermediate in the cortex, thalamus, striatum, hippocampus, and hypothalamus, and lowest in the midbrain and medulla/pons. Pharmacological studies indicated that only secretin, but not other peptides, inhibits binding of $\left[{ }^{125} \mathrm{I}\right]$ secretin with high affinity. Also, certain guanine nucleotides inhibited high affinity binding. These data indicate that rat brain membranes possess high affinity binding sites specific for secretin and that with the use of $\left.{ }^{12 \pi} \mathrm{I}\right]$ secretin the kinetics, stoichiometry, specificity, and distribution of secretin receptors can be directly investigated.
\end{abstract}

It is generally accepted that several peptides initially isolated from peripheral organs are also present in the CNS. Among these are cholecystokinin (CCK) (Vanderhaegen et al., 1975; Muller et al., 1977) and vasoactive intestinal polypeptide (VIP) (Larsson et al., 1976; Said and Rosenberg, 1976). Similarly, receptors have been identified in the CNS which mediate the effects of endogenous CCK (Hays et al., 1980; Innes and Snyder, 1980; Saito et al., 1980) and VIP (Robberecht et al., 1978; Taylor and Pert, 1979). Therefore, these peptides may function as physiologically important neuroregulators in mammalian brain.

A peptide structurally similar to VIP is the 27-amino acid peptide secretin (Mutt et al., 1970). This peptide was initially isolated from porcine intestine and functions as a hormone which stimulates enzyme and electrolyte secretion from the exocrine pancreas. Secretin, similar to other peptides, may function as an important regulatory agent in mammalian brain.

In this regard, secretin-like bioactivity was detected in porcine brain (Mutt et al., 1979) and immunoreactivity in rat and porcine brain extracts (O'Donohue et al., 1981; Charlton et al., 1982). Intracisternal injection of secretin reduces open field activity (Charlton et al., 1981) and alters dopamine metabolism and prolactin secretion (Fuxe et al., 1979) in rats. Also, secretin elevates cAMP

\footnotetext{
${ }^{1}$ To whom correspondence should be addressed.
}

levels in cultured brain cells (Propst et al., 1979) and neuroblastoma $\times$ glioma cell lines (Van Calker et al., 1980). These data indicate that secretin-like peptides are present in the mammalian brain.

Because these endogenous secretin-like peptides may function as synaptic regulatory agents in the CNS, we undertook the characterization of central secretin receptors. Our data indicate that $\left[{ }^{125} \mathrm{I}\right]$ secretin binds with high affinity to a unique class of sites in the CNS. This component may be the physiologically important receptor that mediates the effects of secretin-like peptides in the mammalian brain.

\section{Materials and Methods}

\section{Preparation of radiolabeled peptide}

Five micrograms of secretin (Peninsula Laboratories, Inc., San Carlos, CA) were radiolabeled with $2 \mathrm{mCi}$ of $\mathrm{Na}^{125} \mathrm{I}$ (New England Nuclear, Boston, MA) using $2 \mu \mathrm{g}$ of chloramine T (Sigma Chemical Co., St. Louis, MO) in $0.5 \mathrm{M}$ borate buffer, $\mathrm{pH}$ 8.0. After $2 \mathrm{~min}$ the reaction was quenched by the addition of $20 \mu \mathrm{g}$ of sodium metabisulfite (Sigma). Then $\left[{ }^{125} \mathrm{I}\right]$ secretin was purified using the gel filtration and cation exchange chromatography techniques described previously (Chang and Chey, 1980). The specific activity of our tracer preparations ranged from 600 to $800 \mathrm{Ci} / \mathrm{mmol}$. 


\section{Preparation of membranes}

Adult male Sprague Dawley rats (200 to $250 \mathrm{gm}$ ) were decapitated and the brains were removed. The brain regions were dissected, weighed, homogenized, and centrifuged at $10,000 \times g$ for $20 \mathrm{~min}$. The resulting pellet was resuspended in $100 \mathrm{vol}$ of buffer and incubated for $30 \mathrm{~min}$ at $4^{\circ} \mathrm{C}$. The homogenate was recentrifuged at $10,000 \times g$ for $10 \mathrm{~min}$, and the pellet was resuspended in $10 \mathrm{vol}$ of cold buffer. Protein content was determined as described (Lowry et al., 1951).

\section{Secretin binding assay}

Routinely, $150 \mu \mathrm{l}$ of freshly prepared homogenate (1.5 $\mathrm{mg}$ of membrane protein) were incubated with $\approx 60 \mathrm{fmol}$

TABLE I

Regional distribution of specific $\left[{ }^{125} I\right]$ secretin binding activity in rat brain

Regions from fresh rat brain were dissected on ice, and the nembranes were prepared as described under "Materials and Methods." Binding assays were performed in triplicate using membranes from each brain region and $0.2 \mathrm{nM}\left[{ }^{125} \mathrm{I}\right]$ secretin. The mean $\pm \mathrm{SEM}$ of at least three separate experiments is indicated.

\begin{tabular}{lc}
\hline \multicolumn{1}{c}{ Region } & Density \\
& fmol/mg of protein \\
Cerebellum & $2.8 \pm 0.21$ \\
Frontal cortex & $1.9 \pm 0.18$ \\
Striatum & $1.7 \pm 0.31$ \\
Hippocampus & $1.3 \pm 0.19$ \\
Thalamus & $1.1 \pm 0.18$ \\
Hypothalamus & $1.0 \pm 0.20$ \\
Medulla/pons & $0.29 \pm 0.11$ \\
Midbrain & $0.15 \pm 0.15$ \\
\hline
\end{tabular}

of $\left[{ }^{125} \mathrm{I}\right]$ secretin at $37^{\circ} \mathrm{C}$ for $60 \mathrm{~min}$ in the presence or absence of competitor. The buffer was $10 \mathrm{mM}$ HEPES ( $\mathrm{pH} 7.4$ ) which contained $1 \% \mathrm{BSA}, 1 \mathrm{mg} / \mathrm{ml}$ of bacitracin, and $1 \mathrm{mM} \mathrm{MgCl}_{2}$; total volume was $0.4 \mathrm{ml}$. Membranebound $\left[{ }^{125} \mathrm{I}\right]$ secretin was separated from free peptide by centrifugation using a Beckman Microfuge B (1 min). The incubation mixture was applied to buffer which contained $0.32 \mathrm{M}$ sucrose. After centrifugation, the supernatant was removed and the top of the pellet was washed twice with $1 \mathrm{ml}$ of buffer. The pellet was assayed for radioactivity using a LKB gamma counter.

\section{Results}

\section{Regional distribution studies}

Initially, $\left[{ }^{125} I\right]$ secretin was bound to crude rat brain homogenate. Table I shows, however, that there is a discrete regional distribution of high affinity binding sites for secretin. Binding was highest in the cerebellum, intermcdiatc in the frontal cortex, striatum, hippocampus, thalamus, and hypothalamus, and lowest in the medulla/pons as well as the midbrain. The distribution of $\left[{ }^{125} \mathrm{I}\right]$ secretin-binding sites ranged approximately 18 fold. As rat cerebellar membranes had the highest secretin binding, these membranes were used in subsequent experiments.

\section{Binding to cerebellar membranes}

Figure 1 shows that a centrifugation assay was developed for $\left[{ }^{125} \mathrm{I}\right]$ secretin binding to cerebellar membranes. The background value for the binding assay was $150 \mathrm{cpm}$ ( $0.3 \%$ of the total radioactivity added). As a function of added homogenate the counts per minute increased lin-

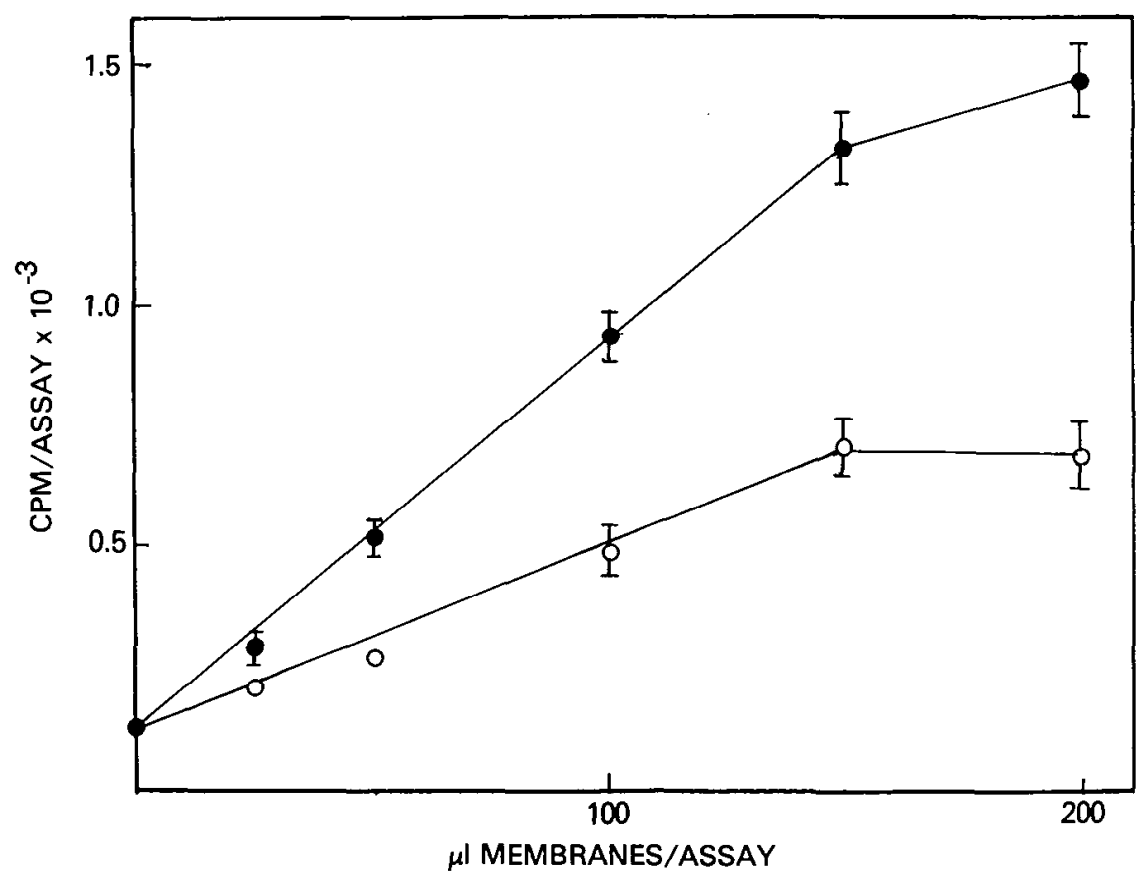

Figure 1. Binding of $\left[{ }^{125} \mathrm{I}\right]$ secretin to rat cerebellar homogenate. $\left[{ }^{125} \mathrm{I}\right]$ Secretin $(0.16 \mathrm{nM})$ was incubated with varying doses of brain homogenate for $60 \mathrm{~min}$ in the presence $(O)$ and absence $(O)$ of $0.15 \mu \mathrm{M}$ secretin. Then bound peptide was separated from free using the sucrose density gradient centrifugation techniques described under "Materials and Methods." Each value represents the mean \pm SEM of three determinations. 
early. Using $150 \mu \mathrm{l}$ of membranes (30 $\mathrm{mg}$ of wet tissue) the total binding was approximately $1350 \mathrm{cpm}(3.1 \%$ of the total counts per minute added), whereas nonspecific binding was $700 \mathrm{cpm}$ (1.6\% of total). Greater membrane densities were not used due to incomplete pelleting of the membranes.

\section{Kinetics of binding}

The time course of $\left[{ }^{125} \mathrm{I}\right]$ secretin binding to and dissociation from rat ccrebcllar membranes was investigated. Figure 2 shows that nonspecific low affinity binding was maximal after approximately $10 \mathrm{~min}$. In comparison, total binding was maximal after $60 \mathrm{~min}$. The difference between the two represents specific high affinity binding which was linear for approximately the first $8 \mathrm{~min}$, then increased slowly until $60 \mathrm{~min}$, when it was maximal; halfmaximal binding occurred at approximately $8 \mathrm{~min}$. The high affinity binding of radiolabeled secretin was reversible. Figure 3 shows that high affinity hinding of $\left[{ }^{125} \mathrm{I}\right]$ secretin declined in an exponential manner after addition of unlabeled secretin and that after $20 \mathrm{~min} 30 \%$ and after 60 min $60 \%$ of the specific binding had dissociated. The calculated association $\left(k_{1}\right)$ and dissociation $\left(k_{-1}\right)$ rate constants were $1.8 \times 10^{8} \mathrm{~min}^{-1} \mathrm{M}-1$ and $1.4 \times 10^{-2} \mathrm{~min}^{-1}$, respectively. Based on these kinetic parameters, the calculated dissociation rate constant $\left(K_{d}=k^{-1} / k^{1}\right)$ was 0.8 $\times 10^{-10} \mathrm{M}$.

\section{Equilibrium binding}

The concentration dependence of $\left[{ }^{125} \mathrm{I}\right]$ secretin binding to rat cerebellar membranes was investigated. Figure 4

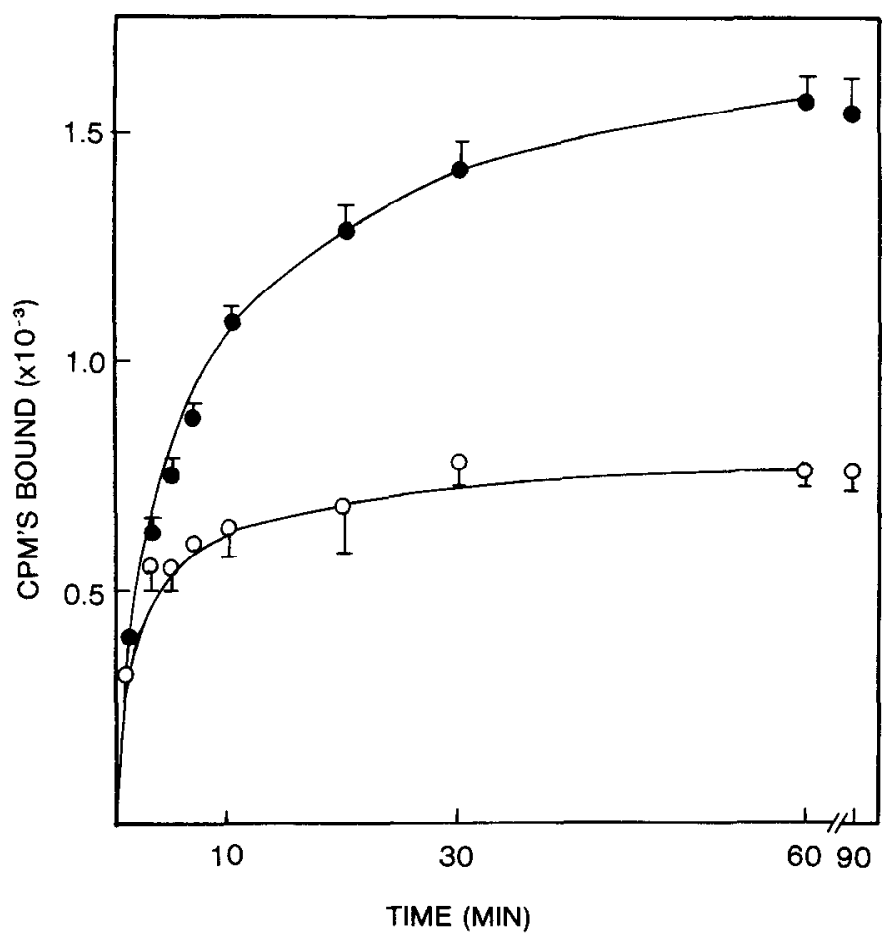

Figure 2. Association of $\left[{ }^{125} \mathrm{I}\right]$ secretin with rat cerebellar membranes. Radiolabeled secretin $(0.2 \mathrm{nM})$ was incubated with cerebellar membranes (30 $\mathrm{mg}$ of wet tissue) at $37^{\circ} \mathrm{C}$ in the presence (O) and absence (O) of $1 \mu \mathrm{M}$ unlabeled secretin. As a function of time after addition of tracer, the amount of $\left.{ }^{125} \mathrm{I}\right]$ secretin bound to the brain homogenate was determined. Each value represents the mean $\pm \mathrm{SEM}$ of three determinations.

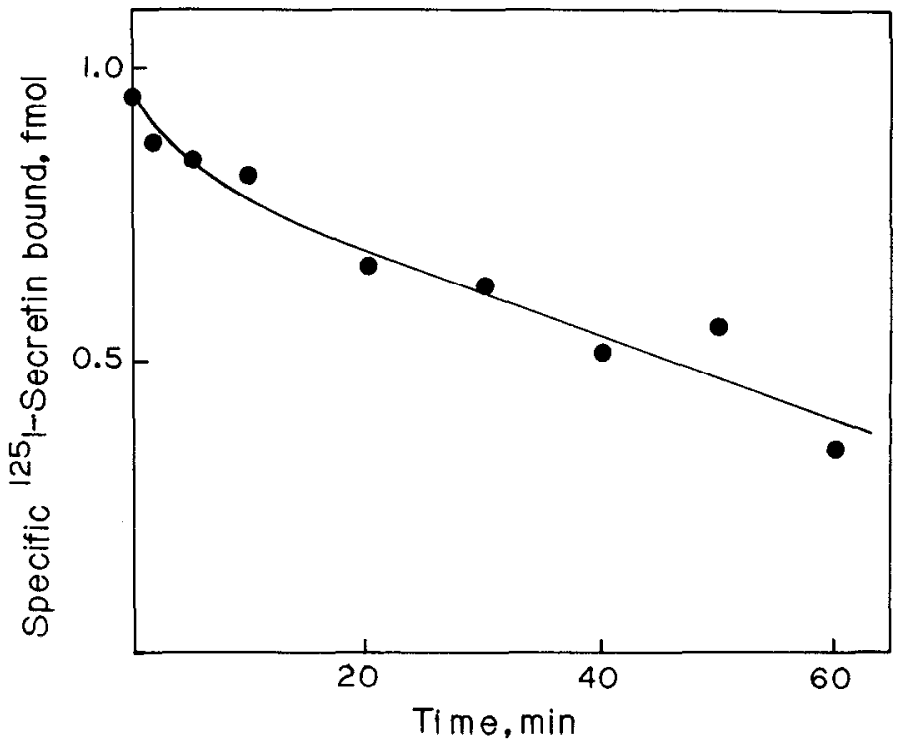

Figure 3. Dissociation of bound $\left.{ }^{[25} \mathrm{I}\right]$ secretin. Radiolabeled secretin $(0.15 \mathrm{nM})$ was incubated with cerebellar homogenate (30 $\mathrm{mg}$ of wet tissue) for $60 \mathrm{~min}$ at $37^{\circ} \mathrm{C}$. Then unlabeled secretin $(1 \mu \mathrm{M})$ was added. The amount of $\left[{ }^{125} \mathrm{I}\right]$ secretin bound specifically as a function of time after addition of competitor is indicated.

shows that nonspecific binding was a linear function of radiolabeled secretin concentration. In comparison, specific binding increased linearly at low tracer concentration $(0.1 \mathrm{nM})$ and then increased slowly and was saturable at high concentrations of $\left.{ }^{125} \mathrm{I}\right]$ secretin $(1.0 \mathrm{nM})$. Figure 5 shows that a Scatchard replot of the specific binding data was linear (Scatchard, 1949). Based on these equilibrium binding data the $K_{d}$ was $0.16 \mathrm{~nm}$ and the density of high affinity [ $\left.{ }^{125} \mathrm{I}\right]$ secretin-hinding sites was $8.7 \mathrm{fmol} /$ mg of protein.

\section{Pharmacology of binding}

The ability of various peptides to inhibit the high affinity binding of $\left.{ }^{125} \mathrm{I}\right]$ secretin to rat cerebellar membranes was investigated. Figure 6 shows that secretin and some structurally related peptides inhibit the specific binding of radiolabeled secretin in a dose-dependent manner reminiscent of competitive inhibition. Secretin was the most potent in that $10 \mathrm{~nm}$ unlabeled secretin inhibited almost all specific binding of [ $\left.{ }^{125} \mathrm{I}\right]$ secretin, and the concentration which inhibited $50 \%$ of the specific binding $\left(\mathrm{IC}_{50}\right)$ was $0.4 \mathrm{nM}$. In comparison, the $\mathrm{IC}_{50}$ values for VIP and porcine heptacosapeptide (PHI) were 0.3 and $1.2 \mu \mathrm{M}$, respectively. Because the $K_{i}=\mathrm{IC}_{50} /(1+\mathrm{L} /$ $K_{d}$ ), the calculated $K_{i}$ values for secretin, VIP, and PHI are $0.2 \mathrm{nM}, 0.15 \mu \mathrm{M}$, and $0.6 \mu \mathrm{M}$, respectively (Cheng and Prusoff, 1973). Other peptides tested which did not compete for $\left[{ }^{125} \mathrm{I}\right]$ secretin binding using a $1 \mu \mathrm{M}$ dose include: bombesin, bradykinin, CCK, endorphin, enkephalin, lutcinizing hormonc-releasing hormone, motilin, $\alpha$-melanocyte-stimulating hormone, neurotensin, physalaemin, somatostatin, substance $P$, thyrotropin-releasing factor, and glucagon.

\section{Effects of guanine nucleotides}

Previously, secretin was demonstrated to elevate c $\Lambda$ MP levels in cultured brain cells and neuroblastoma 


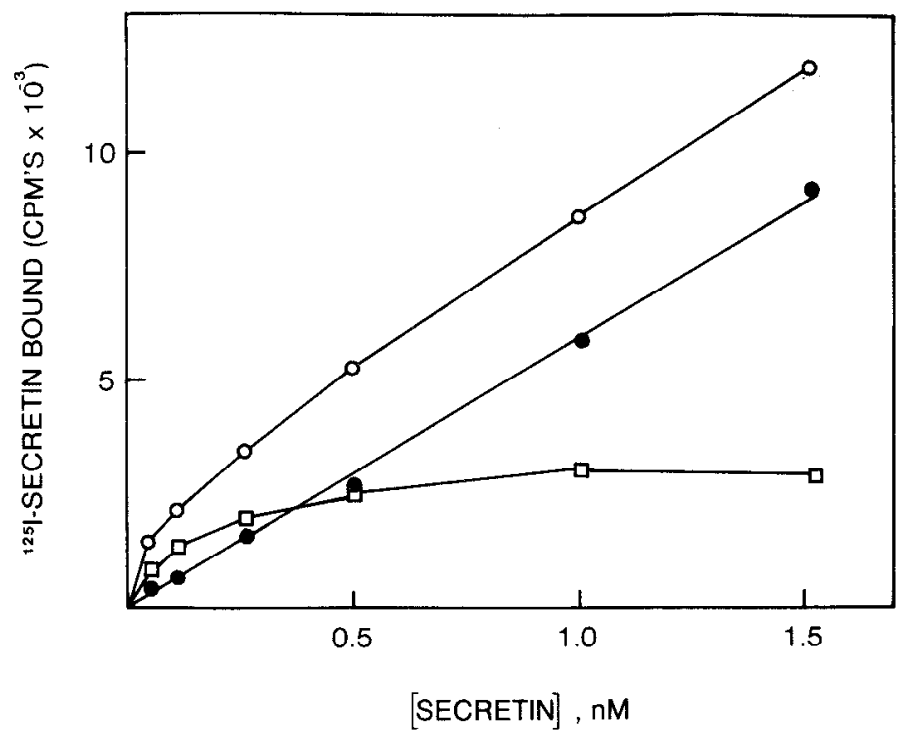

Figure 4. Binding of $\left[{ }^{125} \mathrm{I}\right]$ secretin as a function of radiolabeled peptide concentration. Total $(O)$ and nonspecific (O) binding was determined in triplicate at equilibrium. The difference between the two represents specific binding $(\square)$.

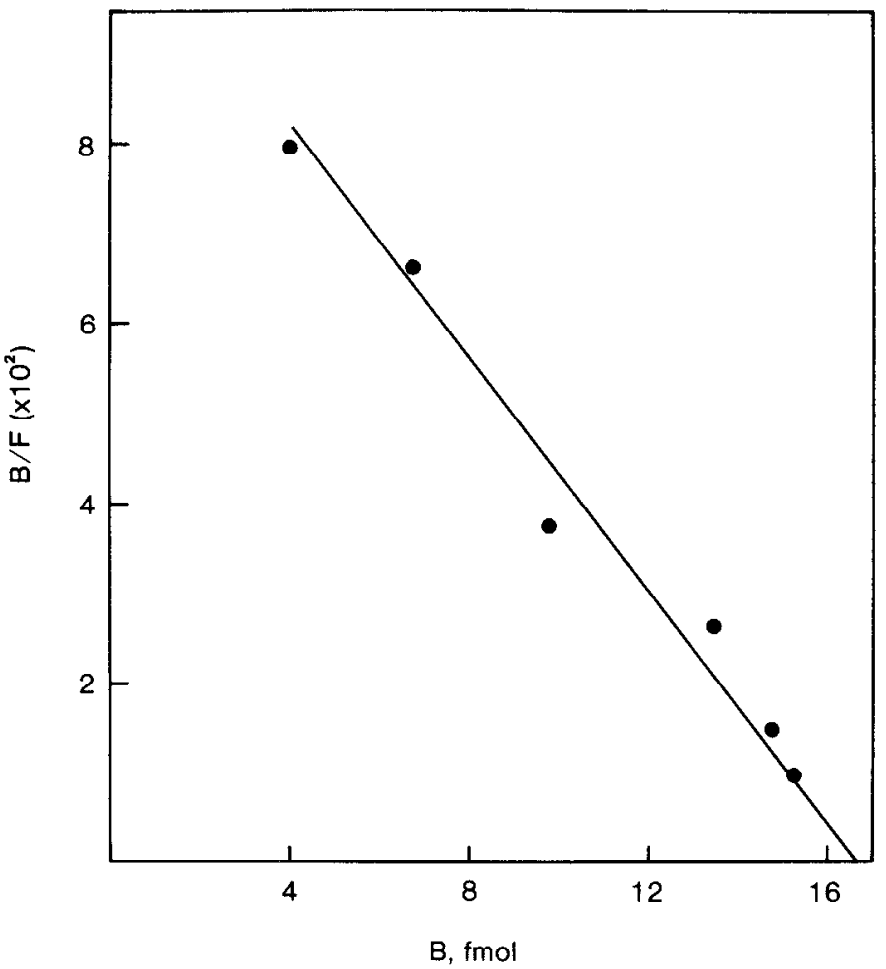

Figure 5. Scatchard plot of specific $\left[{ }^{125} \mathrm{I}\right]$ secretin binding. The specific binding data obtained at equilibrium (Fig. 4) were replotted by the method of Scatchard (1949). The line drawn represents the best fit assuming a single class of binding sites.

$\times$ glioma cell lines (Propst et al., 1979; Van Calker et al., 1980). Also, guanine nucleotides negatively modulate binding of polypeptides to receptors (Rodbell et al., 1971; Robberecht et al., 1978; Moody et al., 1981). Therefore, the effects of guanine nucleotides on CNS secretin binding were investigated. Table II shows that high affinity binding of ${ }^{125}$ I] secretin was inhibited using GMP$\mathrm{P}(\mathrm{NH}) \mathrm{P}$, GTP, GDP, and GMP $(20 \mu \mathrm{M})$ by $65,31,30$,

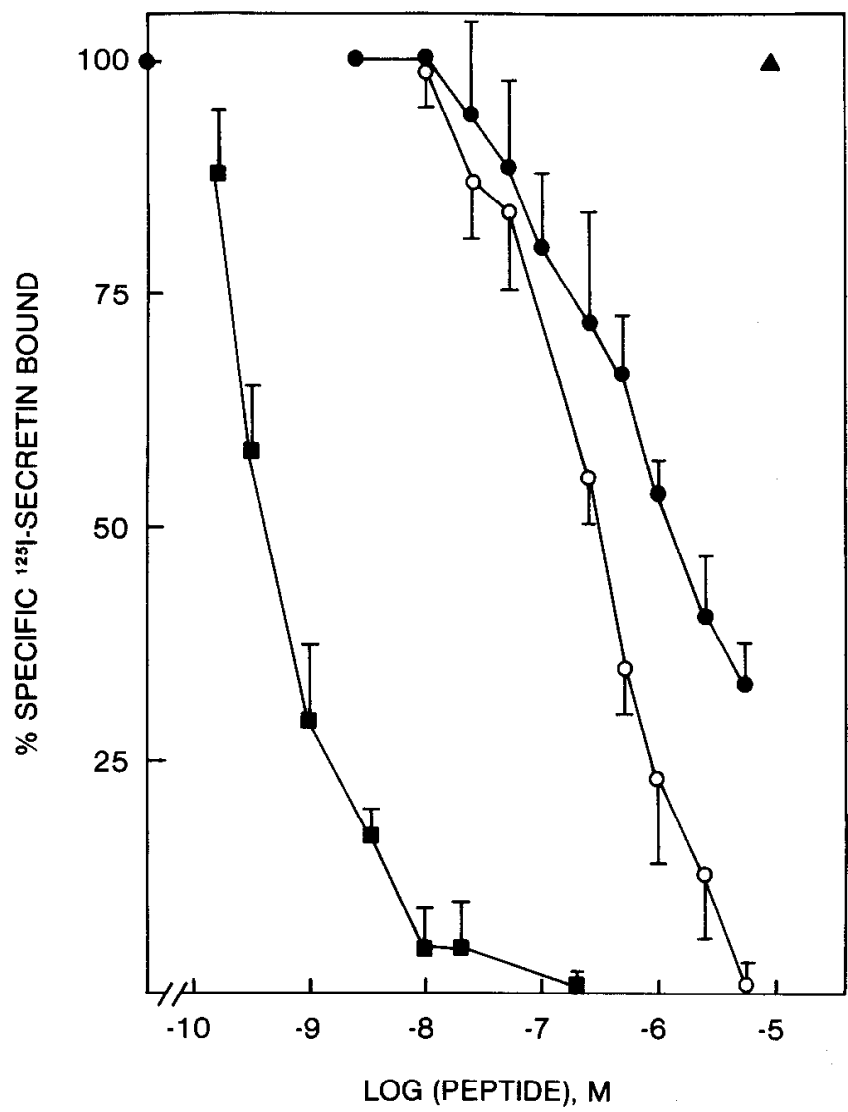

Figure 6. Pharmacology of $\left[{ }^{125} \mathrm{I}\right]$ secretin binding. The percentage of $\left[{ }^{125} \mathrm{I}\right]$ secretin bound specifically is plotted as a function of unlabeled peptide concentration for secretin $(\mathbf{Q})$, VIP $(\bigcirc)$ PHI ( ), and glucagon $(\boldsymbol{\Delta})$. Each assay was performed in triplicate, and the mean $\pm \mathrm{SD}$ of three experiments is indicated. The concentration of $\left[{ }^{125} \mathrm{I}\right]$ secretin was $0.15 \mathrm{nM}$.

TABLE II

Inhibition of specific $\left[{ }^{125} I\right]$ secretin binding by guanine nucleotides Nucleotides $(20 \mu \mathrm{M})$ were incubated with membranes for $10 \mathrm{~min}$ at $37^{\circ} \mathrm{C}$. Then $\left[{ }^{125} \mathrm{I}\right]$ secretin was added, and the binding assay was performed as described under "Materials and Methods." Each assay was performed in triplicate, and the mean $\pm \mathrm{SD}$ of four determinations is indicated.

\begin{tabular}{lc}
\hline \multicolumn{1}{c}{ Nucleotide } & Specific Binding \\
\hline & $\%$ \\
None & $100 \pm 6$ \\
GMP-P(NH)P & $35 \pm 14$ \\
GTP & $69 \pm 11$ \\
GDP & $70 \pm 12$ \\
GMP & $89 \pm 8$ \\
ATP & $93 \pm 9$ \\
CTP & $91 \pm 7$ \\
ITP & $90 \pm 6$ \\
UTP & $90 \pm 5$
\end{tabular}

and $11 \%$, respectively. Therefore, GMP-P $(\mathrm{NH}) \mathrm{P}$ inhibits specific binding of radiolabeled secretin strongly, GTP and GDP moderately, and GMP weakly. Other nucleotide triphosphates tested, such as ATP, cytidine $5^{\prime}$ triphosphate (CTP), $5^{\prime}$-inosinetriphosphate (ITP), and uridine triphosphate (UTP), only weakly inhibited specific binding of $\left[{ }^{125} \mathrm{I}\right]$ secretin. 


\section{Discussion}

A general problem in characterizing peptide receptors is the low receptor densities. Therefore, it is important to utilize receptor probes of high specific activity which retain biological activity and tissues which contain a high density of binding sites. Here $\left[{ }^{125} \mathrm{I}\right]$ secretin was iodinated to a specific activity of 600 to $800 \mathrm{Ci} / \mathrm{mmol}$. Also, when the iodinated peptide was purified to homogeneity using high pressure liquid chromatography techniques, it had appreciable biological activity based on its ability to bind to and elevate intracellular levels of cAMP in dispersed pancreatic acini (R.T. Jensen et al., manuscript in preparation). Because radiolabeled secretin bound best to the rat cerebellum, cerebellar membranes were used as a tissue source in subsequent studies.

The data presented here indicate that cerebellar membranes bind $\left[{ }^{125} \mathrm{I}\right]$ secretin with high affinity. The binding is specific, saturable, and reversible. The dissociation constants calculated from equilibrium $(0.16 \mathrm{nM})$, kinetic $(0.08 \mathrm{nM})$, and competition studies $(0.20 \mathrm{nM})$ agree well. These data indicate that secretin binds with high affinity to a single class of noninteracting sites $(8.7 \mathrm{fmol} / \mathrm{mg}$ of protein). In comparison, other peptides such as bombesin (Moody et al., 1978), CCK (Hays et al, 1980; Innes and Snyder, 1980; Saito et al., 1980), and neurotensin (Kitabgi et al., 1977; Uhl et al., 1977) bind to CNS receptor sites with slightly lower affinity $\left(K_{d} \simeq 1 \mathrm{nM}\right)$, but the density of sites is greater $(\simeq 100 \mathrm{fmol} / \mathrm{mg}$ of protein $)$.

Numerous amino acid residues throughout the secretin sequence may be required for high affinity receptor binding. VIP, which has 9 sequence homologies with secretin (Said and Mutt, 1970), binds with low affinity to these secretin binding sites $\left(K_{i}=0.15 \mu \mathrm{M}\right)$. Similarly, PHI, which has 11 sequence homologies with secretin (Tatemoto and Mutt, 1981), binds with low affinity to these secretin-binding sites $\left(K_{i}=0.6 \mu \mathrm{M}\right)$. Because VIP and PHI inhibit $\left[{ }^{125} \mathrm{I}\right]$ secretin binding by almost 3 orders of magnitude lower affinity than does secretin, these data demonstrate that rat brain membranes may have a specific high affinity receptor for secretin.

Previously, receptors were identified in the rat brain which bind VIP with high $\left(K_{d}=1 \mathrm{nM}\right)$ and secretin with low $\left(K_{d}=1 \mu \mathrm{M}\right)$ affinity (Robberecht et al., 1978; Taylor and Pert, 1979). These VIP-preferring receptors are highly concentrated in the striatum, hippocampus, cortex, and thalamus, whereas the VIP receptor density is low in the hypothalamus, cerebellum, and medulla/pons. In contrast, secretin binding was highest in the cerebellum, intermediate in the cortex, striatum, hippocampus, thalamus, and hypothalamus, and lowest in the midbrain and medulla/pons. Because secretin binds with similar affinity in all brain regions examined, this difference is reflected in the receptor density. Therefore, besides having a different pharmacology, the CNS secretin and VIP receptors have a different regional distribution. Also, VIP-preferring receptors are present in exocrine cells of the guinea pig pancreas (Christophe et al., 1976), rat liver plasma membranes as well as adipocytes (Desbuquois et al., 1973; Frandsen and Moody, 1973; Bataille et al., 1974; Desbuquois, 1974) and guinea pig epithelial cells (Binder et al., 1980). High affinity receptors for secretin in the periphery have only been demonstrated in pancreatic acinar cells (Jensen and Gardner, 1981).

Secretin receptors in the pancreas utilize cAMP as a second messenger. In cultured brain neurons and neuroblastoma $\times$ glioma hybrid cells secretin stimulates adenylate cyclase (Propst et al., 1979; Van Calker et al., 1980). Also, guanine nucleotides such as GMP-P(NH)P negatively modulate binding of polypeptides to receptors coupled to adenylate cyclase (Rodbell et al., 1971). Because GMP-P(NH)P strongly inhibits high affinity binding of $\left[{ }^{125} \mathrm{I}\right]$ secretin to brain homogenate, this indicates indirectly that CNS receptors for secretin may be coupled to adenylate cyclase.

Central secretin receptors are likely activated by endogenous secretin-like peptides. By radioimmunoassay these peptides are present in high density in the rat thalamus as well as hypothalamus, in moderate density in the striatum, septum, cerebellum, and midbrain, and in low density in the cerebral cortex and medulla/pons (O'Donohue et al., 1981). Therefore, the density of immunoreactive secretin does not always parallel the concentration of secretin receptors. This may result because cell bodies which synthesize the secretin in the hypothalamus and thalamus may terminate in other brain regions.

The regional distribution of receptors for secretin is somewhat unusual, being highly concentrated in the cerebellum and intermediate in the cortex, striatum, hippocampus, thalamus, and hypothalamus. Because GABA receptors are highly concentrated in the cerebellum (Zukin et al., 1974), it remains to be determined if secretin has any relationship with neurotransmitters such as GABA. Central receptors for secretin may mediate the behavioral and respiratory effects caused by intraventricular administration of secretin (Charlton et al., 1981). Also, hypothalamic secretin receptors, when activated, may enhance dopamine metabolism resulting in decreased prolactin secretin from the pituitary (Fuxe et al., 1979). The physiological role of secretin receptors in brain loci such as the cerebellum has yet to be elucidated.

\section{References}

Bataille, D., P. Freychet, and G. Rosselin (1974) Interactions of glucagon, gutglucagon, vasoactive intestinal polypeptide and secretin with liver and fat plasma membranes: Binding to specific sites and stimulation of adenylate cyclase. Endocrinology 95: 713-721.

Binder, H. J., G. F. Lemp, and J. D. Gardner (1980) Receptors for vasoactive intestinal peptide and secretin on small intestinal epithelial cells. Am. J. Physiol. 238: G190-G196.

Chang, T. M., and W. Y. Chey (1980) Radioimmunoassay of secretin: A critical review and current status. Dig. Dis. Sci. 25: 529-552.

Charlton, C. G., T. L. O'Donohue, R. L. Miller, J. N. Crawley, and D. M. Jacobowitz (1981) Secretin in rat brain: Localization, characterization and behavioral effect. Soc. Neurosci. Abstr. 7: 508.

Charlton, C. G., T. L. O’Donohue, R. L. Miller, and D. M. Jacobowitz (1982) Secretin in the rat hypothalano-piluilary system: Localization, identification and characterization. Peptides 3: 565-567.

Cheng, Y. C., and W. H. Prusoff (1973) Relationship between 
the inhibition constant $\left(K_{i}\right)$ and the concentration of an inhibitor which causes $50 \%$ inhibition $\left(\mathrm{IC}_{50}\right)$ of an enzymatic reaction. Biochem. Pharmacol. 22: 3099-3108.

Christophe, J. P., T. P. Conlon, and J. D. Gardner (1976) Interaction of porcine vasoactive intestinal peptide with dispersed pancreatic acinar cells from the guinea pig. J. Biol. Chem. 251: 4629-4634.

Desbuquois, B. (1974) The interaction of vasoactive intestinal polypeptide and secretin with liver cell membranes. Eur. J. Biochem. 46: 439-450.

Desbuquois, B., M. H. Laudat, and P. Laudat (1973) Vasoactive intestinal polypeptide and glucagon: Stimulation of adenylate cyclase activity via distinct receptors in liver and fat cell membranes. Biochem. Biophys. Res. Commun. 53 . 1187-1194.

Frandsen, E. K., and A. J. Moody (1973) Lipolytic action of a newly isolated vasoactive intestinal polypeptide. Horm. Metab. Res. 5: 196-199.

Fuxe, K., K. Andersson, T. Hokfelt, V. Mutt, L. Ferland, L. F. Agnati, D. Ganten, S. Said, P. Eneroth, and J. A. Gustafsson (1979) Localization and possible function of peptidergic neurons and their interactions with central catecholamine neurons and the central action of gut hormones. Fed. Proc. 38 . 2333-2340.

Hays, S. E., M. C. Beinfeld, R. T. Jensen, F. K. Goodwin, and S. M. Paul (1980) Demonstration of a putative receptor site for cholecystokinin in rat brain. Neuropeptides 1: 53-62.

Innes, R. B., and S. H. Snyder (1980) Distinct cholecystokinin receptors in the brain and pancreas. Proc. Natl. Acad. Sci. U. S. A. 77: 6917-6921.

Jensen, R. T., and J. D. Gardner (1981) Identification and characterization of receptors for secretagogues on pancreatic acinar cells. Fed. Proc. 40: 2486-2496.

Kitabgi, P., R. Carraway, J. Van Rietschoten, C. Granier, J. L. Morgat, A. Menez, S. Leeman, and P. Freychet (1977) Neurotensin: Specific binding to synaptic membranes from rat brain. Proc. Natl. Acad. Sci. U. S. A. 74: 1846-1850.

Larsson, L. I., J. Fahrenkrug, O. Schaffalitzky de Muckadell, F. Sundler, R. Hakanson, and J. F. Rehfeld (1976) Localization of vasoactive intestinal polypeptide (VIP) to central and peripheral neurons. Proc. Natl. Acad. Sci. U. S. A. 73: 3197-3200.

Lowry, O. H., N. J. Rosebrough, A. L. Farr, and R. J. Randall (1951) Protein measurement with the Folin phenol reagent. J. Biol. Chem. 193: 265-275.

Moody, T. W., C. B. Pert, J. Rivier, and M. R. Brown (1978) Bombesin: Specific binding to rat brain membranes. Proc. Natl. Acad. Sci. U. S. A. 75: 5372-5376.

Moody, T. W., D. P. Taylor, and C. B. Pert (1981) Effects of guanine nucleotides on CNS neuropeptide receptors. J. Supramolec. Struct. Cell. Biochem. 15: 153-159.

Muller, J. E., E. Straus, and R. S. Yalow (1977) Cholecystokinin and its $\mathrm{COOH}$-terminal octapeptide in the pig brain. Proc. Natl. Acad. Sci. U. S. A. 74: 3035-3037.
Mutt, V., J. E. Jorpes, and S. Magnuson (1970) Structure of porcine secretin. Eur. J. Biochem. 15: 513-519.

Mutt, V., M. Carlquist, and K. Tatemoto (1979) Secretin-like bioactivity in extracts of porcine brain. Life Sci. 25: 1703-1708.

O'Dononue, T. L., C. G. Charlton, R. I. Miller, G. Boden, and D. M. Jacobowitz (1981) Identification, characterization and distribution of secretin immunoreactivity in rat and pig brain. Proc. Natl. Acad. Sci. U. S. A. 78: 5221-5224.

Propst, F., L. Moroder, E. Wünsch, and B. Hamprecht (1979) The influence of secretin, glucagon and other peptides, of amino acids, prostaglandin endoperoxide analogues and diazepam on the level of adenosine $3^{\prime}, 5^{\prime}$-cyclic monophosphate in neuroblastoma $\times$ glioma hybrid cells. J. Neurochem. 32: 1495-1500.

Robberecht, P., P. DeNeef, M. Lammens, M. Deschodt-Lanckman, and J. P. Christophe (1978) Specific binding of vasoactive intestinal peptide to brain membranes from the guinea pig. Eur. J. Biochem. 90: 147-154.

Rodbell, M., H. M. J. Krans, S. L. Pohl, and L. Birnbaumer (1971) The glucagon-sensitive adenylate cyclase system in plasma membrane of the liver. J. Biol. Chem. 246: 1861-1871.

Said, S. I., and V. Mutt (1970) Polypeptide with broad biological activity: Isolation from small intestine. Science 169: 1217-1218.

Said, S. I., and R. H. Rosenberg (1976) Vasoactive intestinal polypeptide: Abundant immunoreactivity in neural cell lines and normal nervous tissue. Science 192: 907-908.

Saito, A., H. Sankaran, I. D. Golfinc, and J. L. Williams (1980) Cholecystokinin receptors in the brain: Characterization and distribution. Science 208: 1155-1156.

Scatchard, G. J. (1949) The attractions of proteins for small molecules and ions. Ann. N. Y. Acad. Sci. 51: 660-679.

Tatemoto, K., and V. Mutt (1981) Isolation and characterization of the intestinal peptide porcine PHI (PHI-27), a new member of the glucagon-secretin family. Proc. Natl. Acad. Sci. U. S. A. 78: 6603-6607.

Taylor, D. P., and C. B. Pert (1979) Vasoactive intestinal polypeptide: Specific binding to rat brain membranes. Proc. Natl. Acad. Sci. U. S. A. 76: 660-664.

Uhl, G. R., J. P. Bennet, and S. H. Snyder (1977) Neurotensin, a central nervous system peptide: Apparent receptor binding in brain membranes. Brain Res. 130:299-313.

Van Calker, O., M. Muller, and R. Hamprecht (1980) Stimulation by secretin, vasoactive intestinal peptide, and somatostatin of cyclic AMP accumulation in cultured brain cells. Proc. Natl. Acad. Sci. U. S. A. 77: 6907-6911.

Vanderhaeghen, J., J. C. Signeau, and W. Gepts (1975) New peptide in the vertebrate CNS reacting with antigastrin antibodies. Nature (Lond.) 257: 604-605.

Zukin, S. R., A. B. Young, and S. H. Snyder (1974) Gammaaminobutyric acid binding to receptor sites in the rat central nervous system. Proc. Natl. Acad. Sci. U. S. A. 71: 4802-4807. 